\title{
The Adolescent Influence in Family Decision-Making: Parents Perception
}

\author{
Roberto de Araújo Nascimento Cunha ${ }^{1} \&$ Pedro José Steiner Neto ${ }^{2}$ \\ ${ }^{1}$ Postgraduate Program in Business Administration, Nove de Julho University (UNINOVE), São Paulo, Brazil \\ ${ }^{2}$ Postgraduate Program in Business Administration, Positive University (UP), Curitiba, Paraná, Brazil \\ Correspondence: Roberto de Araújo Nascimento Cunha, Postgraduate Program in Business Administration, Nove \\ de Julho University (UNINOVE), São Paulo, Brazil. Tel: 55-11-9949-27800. E-mail: \\ robertocunha@hiring.com.br
}

Received: February 13, 2015

Accepted: March 20, 2015

Online Published: April 25, 2015

doi:10.5539/ibr.v8n5p244

URL: http://dx.doi.org/10.5539/ibr.v8n5p244

\begin{abstract}
The family is an important institution on products purchasing in society. Reviewers of family decisions used to consider not only the husband-wife relationship but acknowledges the importance of adolescents in family purchasing decisions. The main purpose of this study is to understand how family members take purchase decisions as a group, by measuring the adolescent level of influence on the acquisition of several selected products. Furthermore, the study investigates if the adolescent level of influence differ depending on the stages of buying decision process, adolescent gender, and the amount of children in the family. The study was conducted in Curitiba city in Brazil and the respondents were family members (husband, wife and adolescent). A sample of 93 families, totaling therefore 279 consumers have been selected for the study. The results show that parents disagree about the intensity of influence from the teenage son from some products; that adolescent gender influences the level of his/her participation; and the amount of children in the family increases his/her level of participation. Furthermore, it's proposed graphically a triangle of influence of family members, by stage of buying decision process and product researched.
\end{abstract}

Keywords: consumer behavior, family purchase decision, adolescent influence

\section{Introduction}

The family is one of the main targets of the promotional appeals of products and services. Davis (1976) states that casual observations suggest that some consumer decisions involve other family members in addition to the husband-wife relationship and acknowledges the importance of child-wife and child-husband interactions on purchase decisions. The attention given to young consumers is justified by their potential consumer market. Jenkins (1979) and McNeal (1992) recognize that the young consumer behavior is the direct antecedent of the behavior of the adult consumer and define a child as a trainee of a consumer. Conquer the adolescent consumer means winning the future consumer.

This study seeks to understand how family members take purchase decisions as a group, by measuring the adolescent level of influence on the acquisition of several selected products. Belch and Willis (2002) and Jenkins (1980) observe the marketing strategists are more concerned with identifying which parent has the dominating influence on the various types of decisions since it is through this knowledge that those professionals will get subsidies to formulate their marketing communication strategies.

The present study aims to verify the following research hypotheses:

H1: Parents' perceptions of the adolescent level of influence differ depending on the stages of buying decision process.

H2: Adolescents' perceptions of their self-perceived level of influence differ depending on their gender.

H3: Parents' perceptions of the adolescent level of influence differ depending on the amount of children in family.

\section{Literature Review}

The context for this paper begins with the discussion of fundamental aspects to understand the behavior of family consumption. Therefore, the role of the adolescent in the family purchase decision will be described here. 


\subsection{The Family: A Social Group and a Unit of Consumption}

According to Chinoy (1975), from a sociological point of view a family is the basic social unit. The family is considered an agent of socialization process that transforms raw material into a human being. The family prepares the individual for the roles he/she will play, providing the necessary repertoire of habits, beliefs and values.

Family life is the first form of sociability, because it is through this that a family member comes into contact with societal norms and essentials that must be learned. The family transmits those to its members, in particular the child, not only directly by teaching and by indoctrination, but also indirectly by training methods, the content of culture, i.e. the socialization (Chinoy, 1975).

Family is the most important consumer buying organization in society. However, recent changes in the family composition and lifestyle, including the increase in the number of divorces and reducing family size suggest that we should re-examine the traditional family life cycle and behavior of family members. In the context of family purchases, new niches of consumers with profiles, habits and attitudes emerged, as the example of childless couples with a discretionary budget superior to couples of the same age group and economic status, with children. These changes have substantially altered family life, their needs and consumer behavior, though preserving the family as an institution.

\subsection{Family Purchasing Behavior}

The family purchasing behavior is a collective process, given that it occurs when two or more individuals involved in the decision-making process. In the process, the participants are not limited to the simple search for information. They also exchange opinions and active participation.

Burns and Granbois (1980) and Davis (1976) highlight that decision-making in the family was considered only with the opinion of the husband and the wife. Today, however, the young plays a fundamental role in the decision (Beatty \& Talpade, 1994; Jenkins, 1980; Thomson et al., 2007; Watne \& Brennan, 2011). The husband is still seen as the dominant member of the family, for being, usually, who brings home the money and is the main resource provider.

However, as elucidated by Corfman (1989), Ferber and Chao Lee (1974) and Spiro (1983), from the moment when the woman works and contributes to the household budget, she increases her decision-making power. Wife's power grows in proportion as intellectual and financial capacity increases, which makes her less dependent on her husband, both in relation to the knowledge of the external world and the ability to evaluate alternatives, as compared to the amount of money you can spend to satisfy their own needs.

According to Davis (1976), several studies focus on the outcome of the decision-making process, not worrying about the process itself. The author analyses the decision result, observing that who decides or who wins the decision, is different from measuring the decision-making process: who starts the process or interrupts it. Researchers should begin to examine the decision-making process as a whole, instead of considering only the decision taker and the final result.

The perception of family members' influence on the buying decision varies by product category, the stage in the decision-making process (Belch \& Willis, 2002; Davis, 1974; Davis \& Rigaux, 1974; Wu et al., 2010), the sub decisions (Belch \& Belch, 1985; Belch \& Willis, 2002), the product user under consideration and its cost (Foxman \& Tansuhaj, 1988). The level of importance and use of the product are also directly related to the perception of influence (Foxman \& Tansuhaj, 1988). According to the authors, the influence of family members is distinguished by product user - there are products for children, for parents or for the whole family.

Empirical studies (Davis \& Rigaux, 1974) have classified family decisions into 4 categories: Husband dominance, wife's dominance, autonomous (when an equal number of separate decisions are taken by each member of the couple) and syncretic (when most decisions are taken jointly). Marchetti (1991), in turn, identifies the influence of family members in 7 different areas: (1) the zone of influence of the husband; (2) the zone of influence of the wife; (3) the zone of influence of the child; (4) the zone of influence of the joint decision of the husband-wife; (5) the zone of influence of the joint decision of the husband-child; (6) the zone of influence of joint decision of wife-child; and (7) the zone of influence of the joint decision of the husband-wife-child. Originally, Marchetti (1991) plays that, from the scores of influence obtained by product browsed, it is possible to create an equilateral triangle of influence, in which each vertex corresponds to each member polled the family: father, mother and child (Figure 1). 


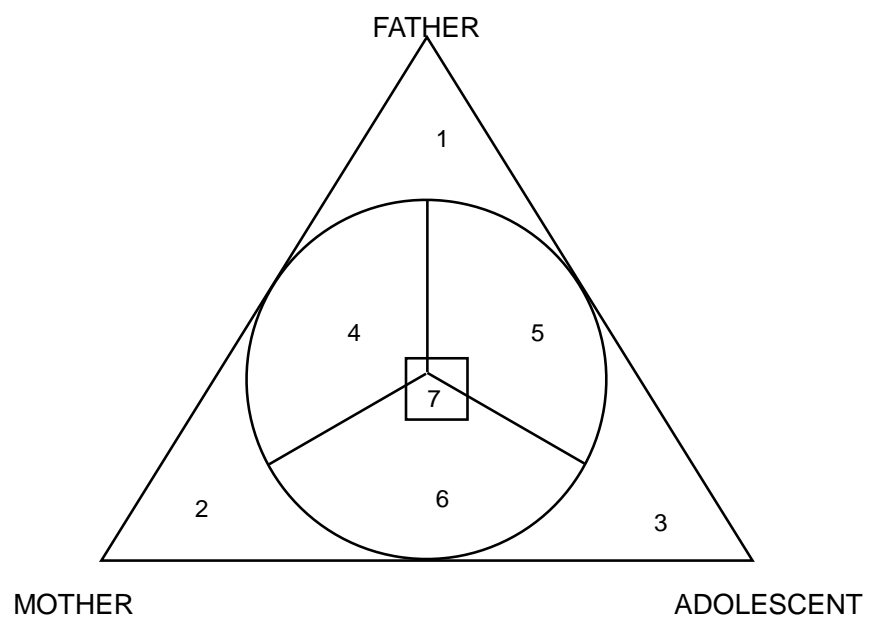

Figure 1. Triangle areas of influence of family purchase decision

\subsection{The Role of the Adolescent in the Family Purchase Decision}

Adolescent purchasing power has increased dramatically on the last years, representing a particular group of consumers (Bristol, 2001; Corfman, 1997; Jenkins, 1979; Wu et al., 2010). It is important for consumer researchers understand the adolescent behavior on the world of consume, either in or out of the family context. Several studies highlight variables that can influence the participation of adolescents in the buying decision (as shown on Table 1).

Table 1. Main considerations about the role of the adolescent on the family purchase decision

\begin{tabular}{|c|c|c|}
\hline Variable & Considerations & Author (s) \\
\hline $\begin{array}{l}\text { Adolescent } \\
\text { influence }\end{array}$ & $\begin{array}{l}\text { Adolescents have a greater influence on the products purchased for } \\
\text { their own use, which they consider important and of which they have } \\
\text { a high knowledge. }\end{array}$ & $\begin{array}{l}\text { Beatty \& Talpade (1994) } \\
\text { Foxman, Tansuhaj \& Ekstrom (1989) } \\
\text { Foxman \& Tansuhaj (1988) }\end{array}$ \\
\hline Income level & $\begin{array}{l}\text { The adolescents influence on purchase decision-making process of } \\
\text { durable goods for the family is higher in families with two sources of } \\
\text { income than those with only one source. The income generated by } \\
\text { the professional occupation of parents influence positively } \\
\text { adolescents on the purchase of durable goods for the family. }\end{array}$ & Beatty \& Talpade (1994) \\
\hline Adolescent's age & $\begin{array}{l}\text { As adolescent matures he/she becomes an influencer and important } \\
\text { source of information for family decisions. When a teenager gets old } \\
\text { enough he/she becomes able to opine on the economic and consumer } \\
\text { skills knowledge. }\end{array}$ & $\begin{array}{l}\text { Beatty \& Talpade (1994) } \\
\text { Mehrotra \& Torges (1977) }\end{array}$ \\
\hline Parents' work hours & $\begin{array}{l}\text { Due to the fact that parents have less time with their children as work } \\
\text { demands them to be away from home, they are driven by a sense of } \\
\text { guilt for not dedicating so much time to their children. They end up } \\
\text { using the extra money that they earn to buy more items for their } \\
\text { children. } \\
\text { Parents who work tend to ask their children to participate on the } \\
\text { house activities, so that the young assume purchasing control earlier. }\end{array}$ & McNeal (1992) \\
\hline $\begin{array}{l}\text { Divergent } \\
\text { Perceptions of } \\
\text { individual influence }\end{array}$ & $\begin{array}{l}\text { The higher the family size and the more hours the mother works } \\
\text { outside the home, the greater the difference in the influence } \\
\text { perception of adolescents by parents. }\end{array}$ & Foxman, Tansuhaj \& Ekstrom (1989) \\
\hline
\end{tabular}




\section{Methodological Procedures}

\subsection{Research Design}

The population of the present study has been restricted to couples, basic unity on the process of family purchase and to one of their adolescent whose age ranged between thirteen to seventeen years old. This adolescent must live with his parents in the same geographic area. Essentially this adolescent must have consumed durable and non-durable products and researched services.

With the objective of obtaining a representative sample of families, the questionnaires were applied in four schools (elementary and high schools) in different neighborhoods of the city of Curitiba, Brazil. The students answered the questionnaires inside their classrooms and took two other independent ones home to be answered by their parents. The students themselves had the commitment of bringing the answered questionnaires in the following week. In order to reduce the potential data collection biases the questionnaire of other family members who play any kind of influence or act directly on the process have been excluded. The same has happened to the ones who have not adapted themselves to the pre-qualification of the sample such as married adolescents; adolescents who work; adolescents who live away from their parents or stepfathers/stepmothers; adolescents who do not study; families led by stepfathers or stepmothers; families with separated parents.

On this study, three products/services were chosen to be researched: the TV set, the supermarket to grocery shopping and the Internet Service Provider. The selected products for the research should meet the criterion of being of common use to all family members in order to avoid the selection of products of individual use or primordially of just some family members once their influence would be notoriously superior making it difficult the measuring of the level of influence of the family members.

In total, 116 valid families were considered, however only 93 families were used in this study (excluding outliers, missing values and those who did not meet the pre-defined profile for this study).

\section{Results and Discussion}

In this section the results of the adolescent participation in family purchase decisions according to parent's perception will be presented. The T Test was used to compare the average of the adolescent participation.

\subsection{General Characteristics of the Quantitative Sampling}

The final sample of this study was based on 93 families. Each family member (father, mother and adolescent) was individually interviewed, totaling therefore 279 consumers. The parent's ages vary from 30 to 67 years old, with the average age around 41 to 50 years old, corresponding $\sim 61 \%$ of the sample. Out of the adolescents interviewed, 36 were male and 57 female. The adolescent's age varies from 13 to 17 years old. Regarding the number of children in families, $64 \%$ of the sample corresponds to families with 2 children and 3\% with 4 or more children. Finally, when parents were asked about the average time worked by day in activities outside their house, 8.96 hours/day were husbands and 6.12 hours/day were wives. A summary of the information of the sample population can be seen on table 1 .

Table 1. Characteristics of the sample population

\begin{tabular}{|c|c|c|c|c|c|}
\hline Age group & Father $(\%)$ & Mother (\%) & Education level & Father $(\%)$ & Mother (\%) \\
\hline Up to 30 years-old & $1 \%$ & - & Less than high school & $10 \%$ & $19 \%$ \\
\hline $31-40$ years-old & $23 \%$ & $32 \%$ & High school graduate & $31 \%$ & $34 \%$ \\
\hline $41-50$ years-old & $61 \%$ & $63 \%$ & Some college & $44 \%$ & $37 \%$ \\
\hline 51-60 years-old & $14 \%$ & $4 \%$ & Postgraduate degree & $15 \%$ & $10 \%$ \\
\hline More than 61 years-old & $1 \%$ & - & Total & $100 \%$ & $100 \%$ \\
\hline Total & $100 \%$ & $100 \%$ & & & \\
\hline Average time worked by day & Father $(\%)$ & Mother (\%) & Number of children in families & $\%$ & \\
\hline Up to 6 hours per day & $10 \%$ & $48 \%$ & 1 child & $13 \%$ & \\
\hline Between 7 and 8 hours per day & $34 \%$ & $21 \%$ & 2 children & $64 \%$ & \\
\hline Between 9 a 10 hours per day & $37 \%$ & $21 \%$ & 3 children & $20 \%$ & \\
\hline More than 11 hours per day & $19 \%$ & $11 \%$ & More than 4 children & $3 \%$ & \\
\hline Total & $100 \%$ & $100 \%$ & & & \\
\hline
\end{tabular}




\begin{tabular}{lclc}
\hline Age of adolescents & Amount (\#) & \multicolumn{1}{c}{ Family profile } & Amount (\#) \\
\hline 13 years-old & 17 & Families with male children & 36 \\
14 years-old & 23 & responders & \\
15 years-old & 18 & Families with female children & 57 \\
16 years-old & 31 & responders & \\
17 years-old & 4 & & \\
Total & $\mathbf{9 3}$ & & \\
\hline
\end{tabular}

\subsection{Adolescent Participation on the Family Purchase Decision}

The results for the analysis of $\mathrm{H} 1$ have been explored on Table 2 and indicate that only in relation to the TV set, in the stage of search and evaluation of alternatives, the parents disagree with the intensity of support from the teenage son. Note also that the level of agreement among members of the couple varies depending on the sample, not allowing for the generalization of the results. However, a managerial analysis would suggest that, for some products, adolescents participate with similar level of influence.

Table 2. Adolescents' participation on the family purchase decision according to parents' perception

\begin{tabular}{|c|c|c|c|c|}
\hline \multirow{2}{*}{ Product / Service } & \multirow{2}{*}{ Stages } & \multicolumn{2}{|c|}{ Perception } & \multirow{2}{*}{ p-value } \\
\hline & & Father & Mother & \\
\hline & Beginning & 17,82 & 19,12 & 0,888 \\
\hline \multirow[t]{3}{*}{ TV set } & Search and evaluation & 9,24 & 11,48 & $\mathbf{0 , 0 2 0}$ \\
\hline & Final Decision & 7,75 & 8,30 & 0,811 \\
\hline & Beginning & 7,12 & 8,92 & 0,079 \\
\hline \multirow[t]{4}{*}{ Supermarket } & Search and evaluation & 5,60 & 5,48 & 0,480 \\
\hline & Final Decision & 5,15 & 4,89 & 0,723 \\
\hline & Beginning & 39,75 & 47,82 & 0,777 \\
\hline & Search and evaluation & 32,51 & 40,97 & 0,484 \\
\hline Internet service provider & Final Decision & 29,22 & 31,35 & 0,765 \\
\hline
\end{tabular}

Figure 2 shows graphically, according to the methodology proposed by Marchetti (1991), the triangle of influence of family members, by stage of buying decision process and product researched. The illustration shows that the decision to choose the supermarket is mainly carried out by women and internet service provider is held by the parent and teenager. 


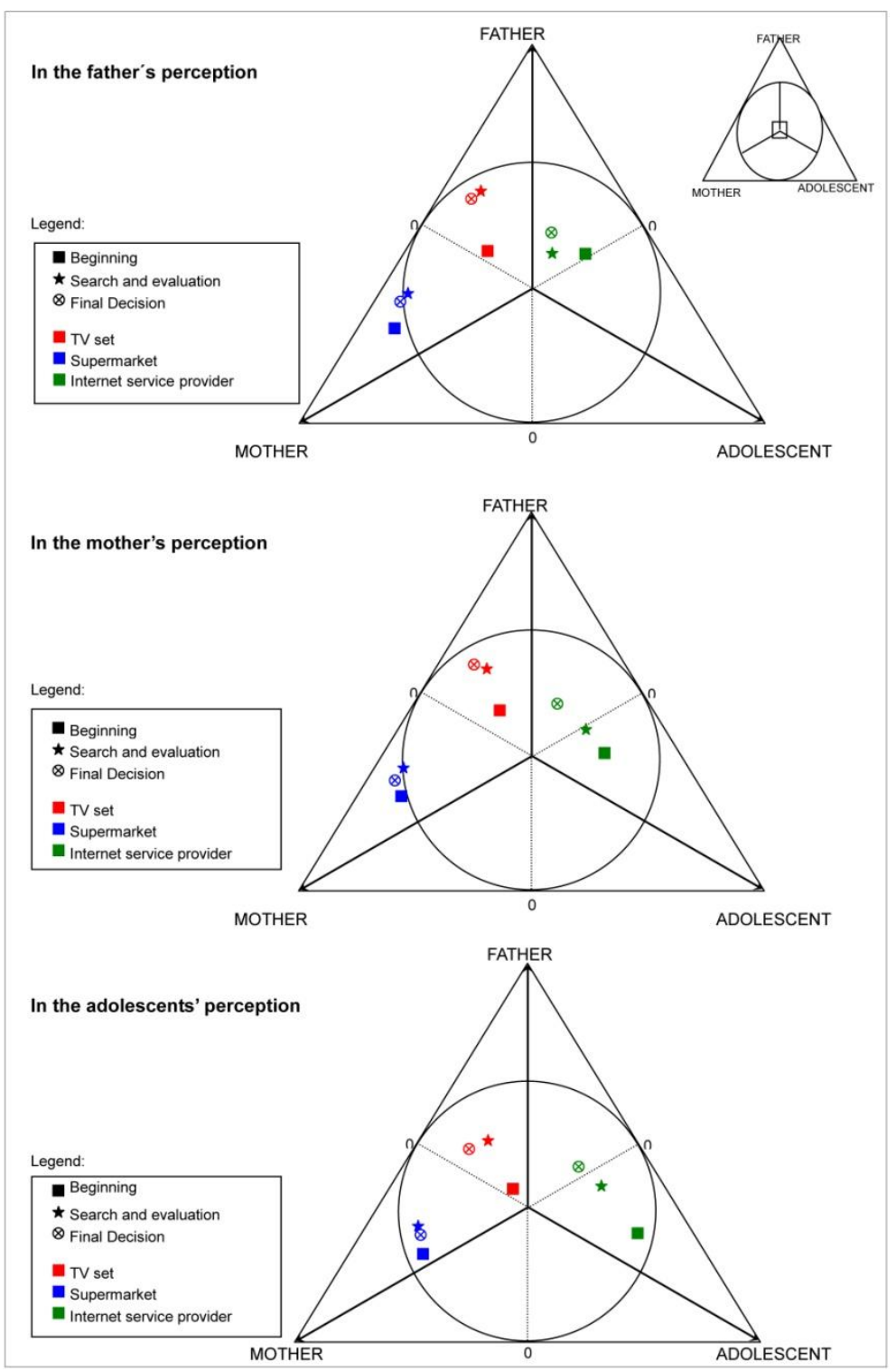

Figure 2. Triangle of Influence of the family purchase decision

According to Table 3, analyzing H2 in the perception of adolescent, gender influences the level of his/her participation. For all products/services surveyed in the stage of final decision of purchase the gender of adolescent has an influence on their participation, statistically, at a significance level of 0.05 .

Table 3. Adolescents' self-perception about their participation on the family purchase decision

\begin{tabular}{lcccc}
\hline Product / Service & Boy (male) & Girl (female) & t & p-value \\
\hline TV set & 32,65 & 17,96 & 2,212 & $\mathbf{0 , 0 3 2}$ \\
Supermarket & 11,56 & 20,27 & $-2,017$ & $\mathbf{0 , 0 4 7}$ \\
Internet service provider & 67,03 & 46,41 & 2,402 & $\mathbf{0 , 0 1 9}$ \\
\hline
\end{tabular}

Regarding the amount of adolescents in the family, on the parents' perception, the fact that there are more children in the family increases the level of participation of these during the initial stage of the buying process. This result allows management reviews to define which marketing strategies can be used with adolescents. According to Table 4, the result of the research sample suggests that in families with more children these have higher level of influence, confirming results from previous studies (Belch \& Willis, 2002). 
Table 4. Adolescent participation in the stages of the family purchase decision process according to family members' perception

\begin{tabular}{|c|c|c|c|c|c|c|c|c|c|c|}
\hline \multirow{2}{*}{$\begin{array}{l}\text { Product / } \\
\text { Service }\end{array}$} & \multirow{2}{*}{ Stages } & \multicolumn{3}{|c|}{ Fathers' perception } & \multicolumn{3}{|c|}{ Mothers' perception } & \multicolumn{3}{|c|}{ Adolescents' perception } \\
\hline & & Up 2 kids & +3 kids & $P$ value & Up 2 kids & +3 kids & P value & Up 2 kids & +3 kids & $P$ value \\
\hline \multirow{3}{*}{$\begin{array}{l}\text { Adolescent } \\
\text { participation }\end{array}$} & Beginning & 17,73 & 27,40 & 0,042 & 20,47 & 31,53 & 0,011 & 31,56 & 34,30 & 0,536 \\
\hline & Search and evaluation & 13,19 & 17,78 & 0,202 & 15,71 & 22,19 & 0,147 & 21,37 & 25,63 & 0,332 \\
\hline & Final Decision & 12,64 & 12,81 & 0,962 & 12,58 & 15,43 & 0,430 & 20,05 & 17,05 & 0,469 \\
\hline
\end{tabular}

\section{Considerations}

The results of this study may be useful to marketers who aim to achieve effectiveness regarding the use of communication strategies for the products surveyed, mainly in products consumed in the family context. It is important to understand which family member more influences every stage of the purchase decision process to direct the companies' marketing campaigns. The results show that the purchasing decisions of the television set or choice of internet service provider were not taken by the husbands only. And also that the supermarket choice decisions were primarily taken by women.

The results concluded that in nearly all products and stages of the buying process the parents agree on the level of participation in buying decision process. In addition to a proposal for expansion of products surveyed, these results could be certainly different according to the adolescent's level of product involvement.

As for the teenager genre, they agree that boys and girls participate differently in buying decisions. This result illustrates a particular consumption behavior for each teenager genre, demonstrating the need to increasingly focus on marketing strategies. Additionally, this result can also be observed by the traditional rivalry of the sexes, in which boys and girls constantly argue over who participates more of the family purchase decision making.

Regarding the variable amount of teenagers, the results show that in families with more children parents tend to share purchases sub-decisions with them. This is a way to socialize and train the teenage consumer for future purchasing decisions. However, the same results show that children found difference in their level of participation, depending on the amount of siblings influencing on the purchasing process. This conclusion may also consider an analytical bias, since children are always dissatisfied with their power to participate in the buying process.

Considering the conclusions, this research is not intended to exhaust the topic of study on family purchase decision, but to present some suggestions for continuity of work within this scope. It is suggested that future research should involve other types of family composition, mostly single-parent families, stepparent families, blended families and grandparent families. In addition, it is suggested the use of other methodological designs, such as a longitudinal study and qualitative analysis.

The study has also certain limitations that are necessary to be pointed out. The first refers to the data collection. Due to budget and time constraints, the data in this study were not collected per household. The sample of households interviewed was obtained from four primary and secondary education schools which each adolescents were directly interviewed in their own classrooms. Data from parental questionnaires were collected by referral through the researched student.

In this case, the data collection instrument may have limitations as: (i) the understanding of the issues; (ii) the control over who answered the questions and (iii) the quality of response - despite we have requested that the questionnaires should be answered individually, without the presence of other family members. Besides that, another limitation was due to the size of the questionnaire applied. The amount of questions may have created a memorization problem and social desirability.

\section{References}

Beatty, S. E., \& Talpade, S. (1994). Adolescent influence in family decision making: A replication with extension. Journal of Consumer Research, 21(2), 332-341. http://dx.doi.org/10.1086/209401

Belch, G. E., \& Belch, M. A. (1985). Parental and teenage child influences in family decision making. Journal of Business Research, 13, 163-176. http://dx.doi.org/10.1016/0148-2963(85)90038-4

Belch, M. A., \& Willis, L. A. (2002). Family decision at the turn of the century: Has the changing structure of households impacted the family decision-making process? Journal of Consumer Behaviour, 2(2), 111-124. 
http://dx.doi.org/10.1002/cb.94

Bristol, T. (2001). Understanding the adolescent's consumption world: Shopping, influencing, deceiving. Advances in Consumer Research, 28(1), 16-19.

Burns, A. C., \& Granbois, D. H. (1980). Advancing the study of family purchase decision making. Advances in Consumer Research, 7(1), 221-226.

Chinoy, E. (1975). Society: An introduction to sociology. Random House.

Corfman, K. (1989). Measures of relative influence in couples: A typology and predictions for accuracy. Advances in Consumer Research, 16(1), 659-665.

Corfman, K. (1997). Children as decision makers. Advances in Consumer Research, 24(1), 125-127.

Davis, H. (1974). Family decision making as conflict management. Advances in Consumer Research, 1(1), 532-535.

Davis, H. (1976). Decision making within the household. Journal of Consumer Research, 2(4), 241-260. http://dx.doi.org/10.1086/208639

Davis, H. L., \& Rigaux, B. P. (1974). Perception of marital roles in decision processes. Journal of Consumer Research, 1(1), 51-62. http://dx.doi.org/10.1086/208581

Ferber, R., \& Chao Lee, L. (1974) Husband-wife influence in family purchasing behavior. Journal of Consumer Research, 1(1), 43-50. http://dx.doi.org/10.1086/208580

Foxman, E. R., \& Tansuhaj, P. S. (1988). Adolescents' and mothers' perceptions of relative influence in family purchase decisions: Patterns of agreement and disagreement. Advances in Consumer Research, 15(1), 449-453.

Foxman, E. R., Tansuhaj, P. S., \& Ekstrom, K. M. (1989). Family members' perceptions of adolescents' influence in family decision making. Journal of Consumer Research, 15(4), 482-491. http://dx.doi.org/10.1086/209187

Jenkins, R. L. (1979). The influence of children in family decision-making: Parents' perceptions. Advances in Consumer Research, 6(1), 413-418.

Jenkins, R. L. (1980). Contributions of theory to the study of family decision-making. Advances in Consumer Research, 7(1), 207-211.

Marchetti, R. (1991). La famille innovatrice: Une analyse du comportement innovateur de la famille brésilienne dans l'achat des produits electroniques. Doctoral thesis, Ecole des Hautes Etudes Commerciales.

McNeal, J. (1992). Kids as consumers: A handbook of marketing to children. Laham: Lexington Books.

Mehrotra, S., \& Torges, S. (1977). Determinants of children's influence on mothers' buying behavior. Advances in Consumer Research, 4(1), 56-60.

Spiro, R. (1983). Persuasion in family decision-making. Journal of Consumer Research, 9(4), 393-402. http://dx.doi.org/10.1086/208933

Thomson, E., Laing, A., \& McKee, L. (2007). Family purchase decision making: Exploring child influence behavior! Journal of Consumer Behaviour, 6(4), 182-202. http://dx.doi.org/10.1002/cb.220

Watne, T., \& Brennan, L. (2011). Behavioral change starts in the family: The role of family communication and implications for social marketing. Journal of Nonprofit \& Public Sector Marketing, 23(4), 367-386. http://dx.doi.org/10.1080/10495142.2011.623526

Wu, K., Holmes, K., \& Tribe, J. (2010). Where do you want to go today? An analysis of family group decisions to visit museums. Journal of Marketing Management, 26(7), 706-726. http://dx.doi.org/10.1080/02672571003780007

\section{Copyrights}

Copyright for this article is retained by the author(s), with first publication rights granted to the journal.

This is an open-access article distributed under the terms and conditions of the Creative Commons Attribution license (http://creativecommons.org/licenses/by/3.0/). 